\title{
Use of HPLC for characterization of sugar and phenolic compounds in Vitis labrusca juice
}

\author{
El uso de HPLC para la caracterización de azúcar \\ y compuestos fenólicos en el jugo de Vitis labrusca \\ Luciane Bertoletti Barros ${ }^{1}$, Louise Larissa May De Mio ${ }^{1}$, Luiz A. Biasi ${ }^{1}$, \\ Frederick Di Profio ${ }^{2}$, Andrew G. Reynolds ${ }^{2}$
}

\begin{abstract}
Two Vitis labrusca cultivars [Bordô (Ives), Concord] grafted to two rootstocks (1103 Paulsen, VR043-43) were combined in a randomized complete block experiment with a factorialized treatment arrangement in southern Brazil. Clusters were sampled over two seasons $(2012,2013)$ and analyzed for Brix, titratable acidity (TA) and pH, sucrose, glucose and fructose, as well as malvidin and cyanidin-3,5-diglucosides, quercetin and trans-resveratrol. Concord had the highest Brix and lowest TA in both years. Total sugars, glucose, and fructose were highest in Bordô/VR043-43 and Concord/1103 Paulsen. Total anthocyanins+quercetin were substantially higher in Bordô compared to Concord and were enhanced in both cultivars by VR043-43, while malvidin was increased in Bordô by VR043-43 as well. Cyanidin was detected in Concord only and was increased by VR043-43 in 2013. Quercetin and trans-resveratrol were detected in Bordô only; quercetin was highest in vines grafted to Paulsen 1103 and trans-resveratrol in those on VR043-43. The results suggest a strong rootstock influence on fruit composition of both cultivars-particularly quercetin and trans-resveratrol, which may have positive health implications in terms of antioxidant capacity.
\end{abstract}

Key words: Concord, rootstocks, anthocyanins, resveratrol.

\section{RESUMEN}

Se evaluaron dos cultivares de Vitis labrusca [Bordô (Ives), Concord] injertadas sobre dos portainjertos (1103 Paulsen, VR04343) en el sur de Brasil. El experimento fue de bloques completos al azar con un arreglo factorial de 2 x 2 con cuatro repeticiones. Se tomaron muestras de dos temporadas $(2012,2013)$ y se analizaron parámetros de calidad: Brix, acidez valorable $(A V)$ y pH; sacarosa, glucosa, y fructosa; malvidina y cianidina-3,5-diglucósidos, quercetina, y el transresveratrol. El cultivar Concord obtuvo un mayor contenido de los sólidos solubles $\left({ }^{\circ}\right.$ Brix) y menor $A V$ en ambas temporadas. Los azúcares totales, glucosa y fructosa, fueron más altos en Bordô/VR043-43 y Concord/1103 Paulsen. Antocianos totales + quercetina fueron sustancialmente más altos en Bordô que Concord y aumento en ambos cultivares cuando se injertarosn sobre VR043-43. Se incrementó Malvidin en Bordô injertado también en VR043-43. Cianidina se detectó solo en Concord y se incrementó en VR043-43 en 2013. La quercetina y transresveratrol se detectaron solo en Bordô; quercetina fue más alta en las vides injertadas en Paulsen 1103, y transresveratrol en VR043-43. Los datos sugieren que el portainjerto influye en la composición de la calidad de frutos en ambos cultivares, particularmente quercetina y transresveratrol, que puede tener efectos positivos en la salud por su capacidad antioxidante.

Palabras clave: Concord, portainjertos, antocianinas, resveratrol.

\section{Introduction}

Grapes contain numerous different phenolic compounds that are present in skin, pulp and seeds; these are partially extracted during grape processing (Jackson, 1994; Maxcheix, 1990). These compounds are important to human health because they have beneficial cardiovascular effects, increase antioxidant capacity and low density lipoprotein resistance, improve endothelial function, and reduce the risk of free radical damage, chronic diseases, hypertension and cancer (Block, 1992; Chou et al., 2001; Delmas et al., 2005; Rice-Evans, et al., 1995; Sugiyama, et al., 2003). Losses in total anthocyanins occur during juice processing, and there are also changes in the color. That happens as a consequence of heating, pressing, pasteurization and enzymatic treatments (Sistrunk and Gascoigne, 1983). Although wine

\footnotetext{
1 Universidade Federal do Paraná, Curitiba, PR, Brazil.

2 Brock University, St. Catharines, ON, Canada.

* Corresponding author: biasi@ufpr.br
}

Fecha de Recepción: 7 Marzo, 2014.

Fecha de Aceptación: 31 Marzo 2014. 
may be considered a predominant resveratrol source (Bhat and Pezzuto, 2002) and has greater antioxidant activity than grape juice (Sanchez-Moreno et al., 1999), juice also is rich in phenolic compounds and antioxidants (Dani et al., 2007; Machado et al., 2011; Rice-Evans et al., 1996).

Vitis labrusca cultivars are important to Brazil, because these and hybrid cultivars represent $>80 \%$ of the volume of grapes processed in this country (Melo, 2008; Prota and Camargo, 2002). The study of different rootstock cultivars is of importance because they induce various vigor levels in the scion, which can result in different concentrations of phenolic compounds. However, information reported in the literature on identification and quantification of phenolic compound in American cultivars is scarce, and information about the phenolic composition of their processed products is even less common. Thus the objective of this research was identify and quantify the concentrations of sugars and phenolic compounds in two V. labrusca cultivars grafted on two different rootstocks cultivated in Brazil's southern region of Campo Largo City, Paraná.

\section{Materials and Methods}

\section{Experimental design}

Bordô (syn. Ives) and Concord vineyards planted in 2008 in southern Brazil (Campo Largo City, Paraná State) were used to evaluate grape juice from the 2012 and 2013 crops. Vines were grafted to Paulsen 1103 (Vitis berlandieri X V. rupestris) and VR 043-43 (V. vinifera $X$ V. rotundifolia) rootstocks, trained to a $2-\mathrm{m}$ high pergola system in four rows with $4.0 \mathrm{~m} \mathrm{X} 2.5 \mathrm{~m}$ row $\mathrm{X}$ vine spacing. The experimental design was randomized complete blocks, with a factorial treatment arrangement $(2 \times 2)$, with each block as a single row that consisted of four replications (whole row blocks) and four vine treatment replicates.

\section{Harvest and berry sampling}

Two-cluster samples were taken from each vine, totaling 32 clusters in each treatment replicate, to measure Brix, titratable acidity (TA), $\mathrm{pH}$, anthocyanins and phenolic compounds. Harvest dates were determined when the berries achieved maturity (minimum $14{ }^{\circ} \mathrm{Brix}$ ) according to the requirements of the Agriculture Ministry (Brasil
1974). The clusters were harvested between early and mid-February in 2012: February 2 (Concord/VR04343 and 1103 Paulsen); February 7 (Bordô/1103 Paulsen); and February 13 (Bordô/VR043-43). In 2013 harvest occurred in mid to late January: January 15 (Bordô/1103 Paulsen and VR043-43); January 26 (Concord/1103 Paulsen); and January 27 (Concord/VR043-43). On the day of harvest the clusters were stored at $10{ }^{\circ} \mathrm{C}$, and they were processed the following day.

\section{Juice extraction}

Two $\mathrm{kg}$ of berries were processed in a $5 \mathrm{-kg}$ capacity juice extractor-cooker in the laboratory of the Department Crop Science and Phytosanitary at Universidade Federal do Paraná. The extractor consisted of four parts: a water tank that generates steam for the extraction of grape pulp; a container with holes where the berries are placed; an external larger container that has a conical opening in the center to allow the passage of steam and a side opening for juice removal and bottling (Rizzon et al., 1998). Initially, water was put in the water tank and the berries were placed in the container with holes. After heating 30 minutes the juice started to be produced. The juice was bottled hot (extraction temperature $75^{\circ} \mathrm{C}$ ) to ensure biological stability without chemical additives (Rizzon et al., 1998), in 300-mL plastic containers, and stored for 14 and 3 months at $-15^{\circ} \mathrm{C}$, for the 2012 and 2013 harvests, respectively.

\section{Brix, pH, and titratable acidity}

Basic juice composition analyses were performed at Brock University, St. Catharines, ON, Canada. The juice containers were thawed overnight at room temperature. Juice samples were then placed into 250-mL beakers. Brix were measured with an Abbé refractometer (model 10450; American Optical Scientific, Buffalo, NY), $\mathrm{pH}$ using an Accumet pH/ ion meter and VWR SympHony electrode and TA by titration with $0.1 \mathrm{~N} \mathrm{NaOH}$ using the PC-Titrate automated titration system (Man-Tech Associates, Guelph, ON, Canada).

\section{Sugar, anthocyanins and phenols}

HPLC analyses of sugars, anthocyanins and phenols were performed at Brock University. To prepare the samples for HPLC analysis, the 
thawed samples were placed in $50-\mathrm{mL}$ test tubes (Fisherbrand), weighed and centrifuged (Sorvall RC-5C Plus, Kendro Laboratory Products, Newton, CT) at $10,000 \mathrm{~g}$ for $15 \mathrm{~min}$ at $24^{\circ} \mathrm{C}$. To extract the sugars, three $1 \mu \mathrm{L}$ replicates of each grape juice and $1 \mu \mathrm{L}$ MilliQ water were passed through a Supelclean Envi-18 cartridge purchased from SigmaAldrich (Oakville, ON). To extract anthocyanins the adsorbed pigments were then washed with $1 \mu \mathrm{L}$ of $\mathrm{MeOH}: \mathrm{AcOH}$ (99:1). The samples were stored at $-18{ }^{\circ} \mathrm{C}$ until HPLC analysis. The sugar standards used were glucose, fructose, and sucrose (10:10:1, respectively) diluted in $100 \mathrm{~mL}$ of MilliQ water in different concentrations $(25,50,75$ and 100 $\mathrm{g} / \mathrm{L})$. Sugars were obtained from Sigma-Aldrich (Oakville, ON). Cyanidin-3,5-diglucoside, malvidin 3,5-diglucoside, peonidin-3,5-diglucoside, quercetin3-glucoside, and trans-resveratrol were obtained from Extrasynthèse SA (Genay, France) and Polyphenols Laboratories AS (Sandnes, Norway).

\section{HPLC analysis}

The samples were analyzed by high performance liquid chromatography (HPLC). An Agilent 1100 Series HPLC (Agilent Technologies, Palo Alto, CA) equipped with a micro vacuum degasser, binary pump, thermostatted micro autosampler, thermostatted column compartment, UV/Vis diode array detector (DAD) and HP ChemStation 3D software was used for identification and quantification. Sugar separation was carried out using a Rezax RCM-Monosaccharide $\mathrm{Ca}+2$ column ( $300 \mathrm{~mm} \times 7.80 \mathrm{~mm}$ ) (Phenomenex, Torrance, CA), with MilliQ water as the mobile phase and a flow rate of $0.6 \mathrm{~mL} / \mathrm{min}$. Post-run time was 10 minutes for a total run time of 24 minutes. Quantification of sugars was performed by generation of a three-point calibration curve of the various sugar standards. Separation of anthocyanin and phenols was carried out using a Zorbax StableBond SB-C18 reversed-phase column ( $50 \mathrm{~mm} \times 4.6 \mathrm{~mm}, 3.5 \mu \mathrm{m})$ (Phenomenex, Torrance, CA) with a Phenomenex SecurityGuard ${ }^{\mathrm{TM}}$ C-18 4-mm guard cartridge using techniques described in detail in Di Profio et al. (2011). The binary mobile phase consisted of $0.2 \%$ trifluoroacetic acid (TFA) (solvent A), and HPLC-grade acetonitrile and 0.2\% TFA (solvent B). Flow rate was $1.0 \mathrm{~mL} / \mathrm{min}$. The gradient was as follows: $5 \% \mathrm{~B}(0 \mathrm{~min}), 35 \% \mathrm{~B}(15 \mathrm{~min}), 100 \%$ B (16-25 min), 5\% B (26 min). The detector was set to wavelengths of $525 \mathrm{~nm}$ (bandwidth $20 \mathrm{~nm}$ ) for anthocyanins and to $365 \mathrm{~nm}$ for quercetin and trans-resveratrol. Anthocyanins were quantified by generation of a three-point calibration curve of the various anthocyanin standards. Post-run time was 10 minutes for a total run time of 36 minutes. All samples and column temperatures were maintained at $30^{\circ} \mathrm{C}$. Sample injection volume was $5 \mu \mathrm{L}$.

\section{Statistical analysis}

All data were analyzed with the $\mathrm{R}$ statistical software package (R Development Team 2013), applying the Tukey HSD test for means separation, $p<0.05$.

\section{Results and Discussion}

The most important aspect for grapes destined for juice processing is sugar content; the fruit was harvested at full maturity and according to the requirements of the Agriculture Ministry (Brasil 1974). The Brix and TA for Concord, independent of rootstock, were different than those of Bordô in the two seasons; Concord had higher Brix and lower TA. The $\mathrm{pH}$ was between 3.0 and 3.3, and there were no differences between the cultivars or rootstocks. Fruit composition was in agreement with the values expected for Brazilian grape juice: Brix $\geq 14, \mathrm{TA} \leq 9.0 \mathrm{~g} / \mathrm{L}, \mathrm{pH} 2.80$ to 3.43 (Brazil, 1974) (Table 1).

Pereira et al. (2008) grafted these cultivars to rootstock 101-14, and obtained comparable results in terms of $\mathrm{pH}$ (between 3.4 and 3.6) and Brix in Bordô (15 Brix) (syn. Folha de Figo in Minas Gerais State), but they found lower Brix in Concord (16 Brix) compared to the present study, and TA values of 12 and $13 \mathrm{~g} / \mathrm{L}$ in Bordô and Concord, respectively. In several different $V$. labrusca-based grape juice products, Santana et al. (2008) determined Brix values of 14.2 to $17.3, \mathrm{pH}$ values of 3.18 to 3.50 and TA values of 8.3 to $9.7 \mathrm{~g} / \mathrm{L}$, while Rizzon and Miele (1995) in the Rio Grande do Sul reported Brix values of 12.8 to $18.9, \mathrm{pH}$ values of 2.80 to 3.43 and TA values of 4.1 to $10.0 \mathrm{~g} / \mathrm{L}$ in several cultivars.

In terms of total sugar $(\mathrm{g} / \mathrm{L})$ Brazilian legislation requires the maximum to be $200 \mathrm{~g} / \mathrm{L}$ (Brazil 1974). Total sugars in this study ranged between 87.8 (Bordô /1103 Paulsen 2013) and 150.6 g/L (Concord/1103 Paulsen 2012) (Table 1), within the ranges (118 to $182 \mathrm{~g} / \mathrm{L}$ ) reported by Rizzon and Miele (1995) and Rizzon et al. (1998) (140 to $180 \mathrm{~g} / \mathrm{L}$ ). Sucrose was 


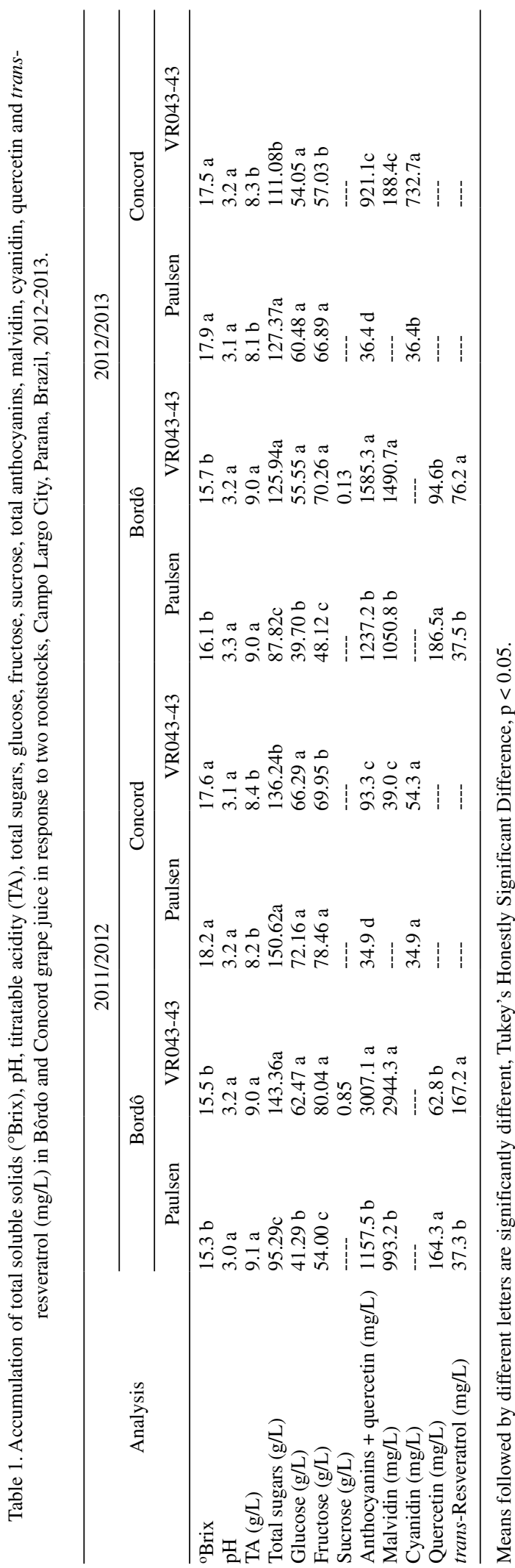

present only in Bordô / VR043-43 (although a small amount), the others did not contain sucrose, and in 2012 it was almost seven times higher than in 2013. Champagnol (1984) verified that at maturation sucrose can be present in small concentrations. At maturation the glucose: fructose ratio is almost 1:1 (Champagnol, 1984) the same as in these results. For fructose, all treatment combinations had higher values in 2012 vs. 2013. Glucose concentration in Concord was also higher in 2012 compared to 2013 and was not affected by rootstock, but Bordô/1103 Paulsen was lower than the other treatments in both years (Table 1). Bordô/VR043-43 and Concord had the highest glucose in both seasons, and Bordô/ Paulsen 1103 had the lowest values. In both years Concord/1103 Paulsen and Bordô/VR043-43 had the highest fructose, and Bordô/VR043-43 had the lowest fructose each year. The fructose and glucose values were about equal in Concord, but in Bordô the fructose concentration was higher than glucose by 10 to $13 \%$. The difference between the treatments can be attributed to the influence of the rootstock; several Brazilian studies have shown differences in vine vigor as well as grape and must composition depending on rootstock, e.g. between 420A Mgt (V. berlandieri X V. riparia) and 196-17 Castel [(V. rupestris X V. vinifera) X V. riparia] (Abe et al., 2007; Alvarenga et al., 2002; Gonçalves et al., 2002).

Four phenolic compounds were identified and quantified (malvidin, cyanidin, quercetin and trans-resveratrol). Bordô always had more phenolic compounds than Concord, and these were greater on VR043-43 rootstock than on 1103 Paulsen. The highest total anthocyanins + quercetin were found in Bordô / VR043-43: 3007 and $1585 \mathrm{mg} / \mathrm{L}$ in 2012 and 2013, respectively, while Concord/ 1103 Paulsen had the lowest total anthocyanins, at 34.9 (2012) and $36.4 \mathrm{mg} / \mathrm{L}$ (2013) (Table 1). Although Concord had the lowest total anthocyanins, they were within the range of 21 to $380 \mathrm{mg} / \mathrm{L}$ found in Concord by Rizzon and Miele (1995) in a study containing 53 samples from different cultivars processed by different methodologies in Rio Grande do Sul. However, compared with other studies of $100 \%$ Concord grape juice the means were generally lower than those reported elsewhere: e.g. Frankel et al. (1998) in Westfield, NY (318.2 and 443.7 $\mathrm{mg} / \mathrm{L}$ ); and Borges et al. (2013) in Southern Brazil $(548.8 \mathrm{mg} / \mathrm{L})$. Many of the differences between this study and others are likely due to sample processing methods. Bordô had comparable mean 
total anthocyanins to previous reports; e.g. Abe et al. (2007) evaluated this cultivar on two different rootstocks (420A and 196-17) in Minas Gerais, Brazil, and measured 248 and $198 \mathrm{mg} / 100 \mathrm{~g}$ total anthocyanins ( $\approx 2480$ and $1980 \mathrm{mg} / \mathrm{L})$.

Concord /1103 Paulsen contained only cyanidin, but on VR043-43 malvidin was also found. There was no seasonal difference for 1103 Paulsen, but VR043-43 in 2013 contained 13.5 and 4.8 times more cyanidin and malvidin, respectively, than in 2012 (Table 1). Wu et al. (2006) utilized HPLC but found higher concentrations of cyanidin (23.8 $\mathrm{mg} / 100 \mathrm{~g} ; \approx 238 \mathrm{mg} / \mathrm{L})$ and malvidin $(5.9 \mathrm{mg} / 100$ $\mathrm{g} ; \approx 59 \mathrm{mg} / \mathrm{L}$ ) in California than the 2011/2012 value. Quercetin was not found in Concord (Table 1), which is consistent with Machado et al. (2011), who evaluated Concord, Isabella and Bordô grape juices obtained from commercial establishments and from cities in Rio Grande do Sul, Brazil. Bordô, regardless of rootstock, always contained malvidin, quercetin and trans-resveratrol but not cyanidin. Bordô/VR043-43 showed the highest concentrations of malvidin and trans-resveratrol. When grafted to Paulsen 1103 there were no seasonal differences, but on VR043-43 it had twice the malvidin and trans- resveratrol in 2012 than in 2013, but onethird less quercetin (Table 1). Machado et al. (2011) also evaluated Bordô juice and they found less mean trans-resveratrol (3.95 and $0.32 \mathrm{mg} / \mathrm{L})$, and quercetin $(8.95$ and $8.47 \mathrm{mg} / \mathrm{L})$, in organic and conventional culture systems, respectively. Abe et al. (2007) also did not find cyanidin in Bordô, in Minas Gerais, but reported malvidin concentrations of 75 and $63 \mathrm{mg} / 100 \mathrm{~g}(\approx 750$ and $630 \mathrm{mg} / \mathrm{L})$ when grafted in rootstocks $420 \mathrm{~A}$ and 196-17, respectively.

\section{Conclusions}

Clusters from two Vitis labrusca cultivars (Bordô, Concord) grafted to two rootstocks (1103/ Paulsen, VR043-43) were sampled over two seasons (2012, 2013) and analyzed for several berry composition variables including standard metrics (Brix, TA and $\mathrm{pH}$ ); individual sugars (sucrose, glucose, and fructose) and total anthocyanins, malvidin and cyanidin-3,5-diglucosides, quercetin and transresveratrol. Concord had the highest Brix and the lowest TA in both years. Total sugars, glucose, and fructose were highest in Bordô/VR043-43 and Concord/1103 Paulsen. Total anthocyanins were substantially higher in Bordô compared to Concord and were enhanced in both cultivars by VR043-43, while malvidin was increased in Bordô by VR043-43 as well. Cyanidin was detected in Concord only and was increased by VR043-43 in 2013. What was noteworthy was that quercetin and trans-resveratrol were detected in Bordô only and in high concentrations; quercetin was highest in vines grafted to 1103 Paulsen and trans-resveratrol in those on VR043-43. The results suggest a strong rootstock influence over fruit composition of both cultivars-particularly quercetin and trans-resveratrol in Bordô, which may have potential positive health implications in terms of the antioxidant capacity of this cultivar.

\section{Acknowledgments}

We thank CNPq for providing funds to this project; CAPES for research support through doctorate scholarship.

\section{Literature Cited}

Abe, L.T.; da Mota, R.V.; Lajolo, F.M.; Genovese, M.I. 2007. Compostos fenólicos e capacidade antioxidante de cultivares de uvas Vitis labrusca L. e Vitis vinifera L. Ciênc. Tecnol. Aliment., 27: 394-400.

Alvarenga, A.A.; Regina, M.A.; Fráguas, J.C.; Chalfun, N.N.J.; da Silva A.L.

2002. Influência do porta-enxerto sobre o crescimento e produção da cultivar de videira Niágara Rosada (Vitis labrusca x Vitis vinifera L.) em condições de solo acido. Ciênc. Agrotecno., 26: 1459-1464.

Bhat, P.L.K.; Pezzuto, J.M.

2002. Cancer chemopreventive activity of resveratrol. Ann. N.Y. Acad. Sci., 957: 210-229.
Block, G.

1992. The data support a role for antioxidants in reducing cancer. Nutr. Rev., 50: 207-213.

Borges, R.S.; Silva, G.A.; Roberto, S.R.; Assis, A.M.; Yamamoto, L.Y.

2013. Phenolic compounds, favorable oxi-redox activity and juice color of 'Concord' grapevine clones. Scientia Horticulturae, 161: 188-192.

Brasil. Ministério da Agricultura.

1974. Complementação de padrões de identidade e qualidade para suco, refresco e refrigerante de uva. Secretaria Nacional de Defesa Agropecuária. Secretaria de Inspeção de Produtos Vegetais. Brasília. 
Champagnol, F.

1984. Elements de physiologie de la vigne et de viticulture générale. Montpellier.

Chou, E.J.; Keevil, J.G.; Aeschliman, S.; Wiebe, D.A; Folts, J.D.; Stein, J.H.

2001. Effect of ingestion of purple grape juice on endothelial function in patients with coronary heart disease. Amer. $J$. Cardiology, 88: 553-555.

Dani, C.; Oliboni, L.S.; Bonatto, D.; Vanderlinde, R.; Salvador,

M.; Henriques, J.A.P.

2007. Phenolic content and antioxidant activities of white and purple juices manufactured with organically-or conventionallyproduced grapes. Food Chem. Toxicol., 45: 2574-2580.

Delmas, D., Jannin, B.; Latruffe, N.

2005. Resveratrol: Preventing properties against vascular alterations and ageing. Molecular Nutrition Food Res., 49: 377-395.

Di Profio, F.; Reynolds, A.G.; Kasimos, A.

2011. Canopy management and enzyme impacts on Merlot, Cabernet franc, and Cabernet Sauvignon. Part II. Wine composition and quality. Am. J. Enol. Vitic., 62: 152-168.

Frankel, E.N.; Bosanek, C.A.; Meyer, A.S.; Silliman, K.; Kirk, L.L. 1998. Commercial grape juices inhibit the in vitro oxidation of human low-density lipoproteins. J. Agric. Food Chem., 46: 834-838.

Gonçalves, C.A.A.; Lima, L.C.O.; Chalfun, N.N.J.; Regina,

M.A.; Alvarenga, A.A.; de Souza, M.T.

2002. Fenologia e qualidade do mosto de videiras 'Folha de Figo' sobre diferentes porta-enxertos, em caldas, Sul de Minas Gerais. Ciênc. Agrotecnol., 26: 1178-1184.

Jackson, R.S.

1994. Wine science: Principles and applications. Academic Press Ltd., New York. ISBN 012379060 3. 474 pp.

Machado, M.M.; Montagner, G.F.F.S.; Boligon, A.; Athayde,

M.L.; Rocha, M.I.U.M.; Lera, J.P.B.; Belló, C.; Cruz, I.B.M.

2011. Determination of polyphenol contents and antioxidant capacity of non-alcoholic red grape products (Vitis labrusca) from conventional and organic crops. Química Nova, 34: 798-803.

Maxcheix, J.J.; Fleuriet, A.; Billot, J.

1990. The main phenolics of fruits. In Fruit Phenolics; CRC Press: Boca Raton, FL, 1990; pp. 1-98.

Mello, L.M.R. de

2009. Vitivinicultura brasileira: panorama 2008. Jornal da Fruta, Lages, 17, 211: 17-21.
Pereira, G.E.; Lima, L.C.O.; Regina, M.A.; Rosier, J.P.; Ferraz, V.; Mourão Jr., M.

2008. Potential evaluation of five American cultivars for grape juices in the south of Minas Gerais state. Ciênc. Agrotec., 32: 1531-1537.

Protas, J.F.S.; Camargo, U.A.; De Melo, L.M.

2002. A vitivinicultura brasileira: realidade e perspectivas, In: Viticultura e Enologia-atualizando conceitos; Caldas: Epamig, 2002, pp. 17-32.

Rice-Evans, C.A.; Miller, N.J.; Paganga, G.

1996. Structure- antioxidant activity relationship of flavonoids and phenolic acids. Free Radical Biology and Medicine, 20: 933-956.

Rizzon, L.A.; Manfroi, V.; Meneguzzo, J.

1998. Elaboração de suco de uva na propriedade vitícola. Bento Gonçalves: EMBRAPA-CNPUV, 24 pp. (Embrapa Uva e Vinho. Documentos, 21).

Rizzon, L.A.; Miele, A.

1995. Características analíticas de suco de uva elaborados no Rio Grande do Sul. Boletim Sociedade Brasileira de Ciência e Tecnologia de Alimentos, 29: 129-133.

R Development Core Team

2006. R: A Language and Environment for Statistical Computing. Vienna: R Foundation for Statistical Computing, 2006.

Sanchez-Moreno, C.; Larrauri, J.A.; Saura-Calixto, F.; Sanchez-

Moreno, C.; Larrauri, J.A.; Saura-Calixto; F.

1999. Free radical scavenging capacity and inhibition of lipid oxidation of wines, grape juices and related polyphenolic constituents. Food Res. Int., 32: 407-412.

Santana, M.T.A.; Siqueira, H.H.; Dos Reis, K.C.; Lima, L.C.O. 2008. caracterização de diferentes marcas de sucos de uva. Ciênc. Agrotec. Lavras, 32: 882-886.

Sistrunk, W.A.; Gascoigne, H.L.

1983. Stability of color in Concord grape juice and expression of color. J. Food Sci., 48: 430-435.

Sugiyama, A.; Saitoh, M.; Takahara, A.; Satoh, Y.; Hashimoto, K. 2003. Acute cardiovascular effects of a new beverage made of wine vinegar and grape juice, assessed using an in vivo rat. Nutrition Res., 23: 1291-1296.

Wu, X.; Beecher, G.R.; Holden, J.M.; Haytowitz, D.B.; Gebhardt, S.E.; Prior, R.L.

2006. Concentrations of anthocyanins in common foods in the United States and estimation of normal consumption. J. Agric. Food Chem., 54: 4069-4075. 